\title{
NOS2P1 Gene
}

National Cancer Institute

\section{Source}

National Cancer Institute. NOS2P1 Gene. NCI Thesaurus. Code C38568.

Human NOS2P1 gene is located within $17 \mathrm{p} 11.2$ and is approximately $14 \mathrm{~kb}$ in length. The product is a processed pseudogene, which produces an RNA transcript but does not encode a protein product. 